\title{
The Effectiveness of Fried Catfish Cake In Increasing Hemoglobin Levels And Oxygen Saturation In Blood In Pregnant Women
}

\author{
Iis Sopiah Suryani ${ }^{*}$, Maria Ulah Jamil ${ }^{1}$, Novianti Rizki Amalia ${ }^{1}$, Ajeng Maharani \\ Pratiwi $^{2}$ \\ ${ }^{1}$ Jurusan Kebidanan, FK, Universitas Bhakti Kencana Tasikmalaya Jl. Re. Martadinata No. 142, Kec. Cipedes \\ Kota Tasikmalaya, Jawa Barat \\ ${ }^{2}$ Universitas Kusuma Husada, Jl. Jaya Wijaya No..11, Kadipiro, Kec. Banjarsari, Kota Surakarta, Jawa Tengah \\ * Corresponding author \\ E-mail: iis.sopiah@bku.ac.id
}

\begin{abstract}
Iron deficiency anemia mainly affects pregnant women, lactating women and women of childbearing age in general. Many things change in pregnant women in the third trimester of pregnancy. In the third trimester, blood volume is still increasing so pregnant women need foods rich in iron and vitamin $\mathrm{C}$ for good iron absorption. Catfish is one of the foodstuffs that is easy to serve and the price is cheaper than other fish. The nutritional content of catfish will increase with the right way of processing. Fresh catfish contains $1.0 \mathrm{mg}$ of iron. After frying, it becomes $1.2 \mathrm{mg}$. With the condition of pregnant women who are prone to anemia, pregnant women must fulfill their nutrition by adding additional food, which can be in the form of snacks made from catfish so that their fe needs will be met. Catfish, apart from being processed into meatballs, can also be processed into the fried catfish cake. Quasi-experimental research type non randomized pre test post test. The research subjects were pregnant women in the third trimester. The analysis of this study used the Paired t test. Results: the results of research that has been conducted regarding differences in Hb levels in pregnant women in the third trimester before and after being given fried catfish cake, it was found that there were differences in $\mathrm{Hb}$ levels before and after treatment, this result was evidenced by the results of the t statistical test where the tcount was 10,816 with a significance level of $\rho_{\text {value }}$ of 0.000 , there is a significant difference because $\rho_{\text {value }}$ is smaller than $\alpha(0.05)$. Meanwhile, for oxygen saturation with the Wilcoxon test statistic, the $Z$ value is -3.345 with a significance level of $\rho_{\text {value }}$ of 0.001 , Thus before and after treatment there is a significant difference because the value is smaller than $\alpha$ (0.05). The brain of fried catfish cake is effective in increasing hemoglobin levels and oxygen saturation in the blood in third trimester pregnant women.
\end{abstract}

Keywords: Anemia, Catfish, Fried, Hemoglobin, Pregnant 


\section{INTRODUCTION}

Iron deficiency anemia is especially prevalent in pregnant women, lactating women and women of childbearing age in general, due to natural functions (menstruation, pregnancy, childbirth, and breastfeeding). This causes the need for $\mathrm{Fe}$ or iron during pregnancy is relatively higher than other groups prone to iron deficiency anemia such as children under five, schoolage children, laborers and low-income workers ${ }^{1}$.

Many things change in pregnant women in the third trimester of pregnancy. According to Wibisono, it is said that in the third trimester of pregnancy, the basal metabolism rises, the appetite is quite good and usually the mother always feels hungry. This is due to the rapid growth of the fetus. The fetus is developing faster than in the previous trimester. Pregnant women whose nutritional needs are insufficient from their daily routine can be met through snack foods (supplementary food). Pregnant women need snacks, but they should be arranged between main meals ${ }^{2}$. Supplementary food which is often referred to as a snack is not only a source of energy, but must also contain protein, various vitamins and various minerals ${ }^{3}$. So that the calorie, protein and iron needs needed by pregnant women can be fulfilled.

In the third trimester, blood volume still increases so pregnant women need foods rich in iron and vitamin $\mathrm{C}$ so that iron absorption is good ${ }^{4}$. Basic Health Research 2013 reported that nationally, anemia sufferers $15-14$ years old were $26.4 \%$ and $18.4 \%$ patients aged $15-24$. Women tend to be at risk of anemia, especially in their teens, the high incidence of early marriage $48 \%$ results in the incidence of anemia which is the effect of teenage pregnancy as much as 48 per 1000 live births. Pregnant conditions with anemia are at risk of maternal death due to childbirth bleeding and children experiencing stunting ${ }^{1}$.

Catfish is one of the foodstuffs that is easy to serve and the price is cheaper than other fish. The nutritional content of catfish will increase with the right way of processing. Fresh catfish contains $1.0 \mathrm{mg}$ iron after frying to $1.2 \mathrm{mg}^{5}$. With the condition of pregnant women who are prone to anemia, pregnant women must fulfill their nutrition by adding additional food, such as snacks made from catfish ingredients so that their iron needs will be met. Catfish, apart from being processed into meatballs, can also be processed into the fried catfish cake.

\begin{tabular}{l}
\hline METHOD \\
\hline This research is a quasi- \\
experimental research type of non \\
randomized pre test post test. The research
\end{tabular}
subjects were pregnant women in the third trimester. In this study, the researchers conducted an assessment of hemoglobin levels and oxygen saturation before and after the intervention. The intervention given was in the form of consuming processed catfish in the form of fried catfish cake.

The sample size study used the Slovin formula ${ }^{6}$. The sample was 21 pregnant women in the third trimester who dropped out because they gave birth to 2 people, so there were 19 people. Data analysis used univariate and bivariate. Univariate analysis aims to explain or describe the characteristics of each research variable $^{7}$. The univariate analysis used is the frequency distribution. The normality test used in this study is Kolmogrov. The bivariate analysis that will be used in this study uses the Paired t test.

\section{RESULT}

Table 1.1 Description of $\mathrm{Hb}$ levels before and after being given fried catfish cake in third trimester pregnant women

\begin{tabular}{|c|c|c|c|c|c|}
\hline $\begin{array}{l}\text { Interven } \\
\text { tion }\end{array}$ & $\begin{array}{c}\text { Treatm } \\
\text { ent }\end{array}$ & $\begin{array}{c}\mathrm{Mi} \\
\mathrm{n}\end{array}$ & $\begin{array}{c}\mathrm{Ma} \\
\mathrm{x}\end{array}$ & Mean & $\begin{array}{c}\text { Std } \\
\text { Deviat } \\
\text { ion } \\
\end{array}$ \\
\hline \multirow{2}{*}{$\begin{array}{l}\text { Fried } \\
\text { catfish } \\
\text { cake }\end{array}$} & Before & $\begin{array}{c}10 \\
3\end{array}$ & $\begin{array}{l}10 \\
90\end{array}$ & $\begin{array}{c}10,61 \\
58\end{array}$ & $\begin{array}{c}0,2061 \\
9\end{array}$ \\
\hline & After & $\begin{array}{c}11, \\
0\end{array}$ & $\begin{array}{l}11, \\
80\end{array}$ & $\begin{array}{c}11,43 \\
16 \\
\end{array}$ & $\begin{array}{c}0,2237 \\
4 \\
\end{array}$ \\
\hline
\end{tabular}

Based on table 1.1 above, it is known that the $\mathrm{Hb}$ level of pregnant women in the 
third trimester before treatment had a minimum value of $10.3 \mathrm{~g} / \mathrm{dl}$ and a maximum $\mathrm{Hb}$ level of $10.90 \mathrm{~g} / \mathrm{dl}$ with a mean of 10.6158 and a standard deviation of 0.20619. Meanwhile, after being given treatment, the minimum $\mathrm{Hb}$ level was 11.0 $\mathrm{g} / \mathrm{dl}$ and the maximum $\mathrm{Hb}$ level was 11.80 $\mathrm{g} / \mathrm{dl}$ with a mean of 11.4316 and a standard deviation of 0.22374 .

Table 1.2 Description of oxygen saturation before and after being given fried catfish cake in third trimester pregnant women

\begin{tabular}{cccccc}
\hline $\begin{array}{c}\text { Interventi } \\
\text { on }\end{array}$ & $\begin{array}{c}\text { Treatme } \\
\mathrm{nt}\end{array}$ & $\begin{array}{c}\mathrm{Mi} \\
\mathrm{n}\end{array}$ & $\begin{array}{c}\mathrm{Ma} \\
\mathrm{x}\end{array}$ & Mean & $\begin{array}{c}\text { Std } \\
\text { Deviati } \\
\text { on }\end{array}$ \\
\hline $\begin{array}{c}\text { Fried } \\
\text { catfish } \\
\text { cake }\end{array}$ & Before & 96 & 99 & $\begin{array}{c}96,94 \\
74\end{array}$ & 1,17727 \\
\hline
\end{tabular}

Based on table 1.2 above, it is known that oxygen saturation in third trimester pregnant women before being given fried catfish cake has a minimum value of $96 \%$ oxygen saturation and a maximum value of 99\% with a mean of 96.9474 and a standard deviation of 1.17727. Meanwhile, after being given the fried catfish cake has a minimum oxygen saturation value of $98 \%$ and a maximum of $99 \%$ with a mean of 98.5263 and a standard deviation of 0.51299 .

Table 1.3 Differences in Hb Levels Before and After Treatment in Third Trimester Pregnant Women

\begin{tabular}{|c|c|c|c|c|c|}
\hline $\begin{array}{l}\text { Interven } \\
\text { tion }\end{array}$ & $\begin{array}{l}\text { Treat } \\
\text { ment }\end{array}$ & Mean & Difference & $T_{\text {count }}$ & $\rho_{\text {value }}$ \\
\hline $\begin{array}{l}\text { Fried } \\
\text { catfish } \\
\text { cake }\end{array}$ & $\begin{array}{l}\text { Before } \\
\text { After }\end{array}$ & $\begin{array}{c}10,61 \\
58 \\
11,43 \\
16\end{array}$ & 0,8158 & $\begin{array}{c}10,8 \\
17\end{array}$ & 0,000 \\
\hline
\end{tabular}

Based on table 1.3 above, it is known that the test results of differences in $\mathrm{Hb}$ levels before and after treatment in third trimester pregnant women have an average before treatment of 10.6158 and an average after treatment of 11.4316 with a difference of 0.8158 . The results of statistical tests obtained tcount value of 10.817 with a significance level (pvalue) of 0.000 , this indicates that there are differences in $\mathrm{Hb}$ levels before and after treatment in third trimester pregnant women.

Table 1.4 Differences in Oxygen Saturation Before and After Treatment in third trimester pregnant women

\begin{tabular}{cccccc}
\hline $\begin{array}{c}\text { Intervent } \\
\text { ion }\end{array}$ & $\begin{array}{c}\text { Treatm } \\
\text { ent }\end{array}$ & Mean & $\begin{array}{c}\text { Differe } \\
\text { nce }\end{array}$ & $Z$ & $\begin{array}{c}\rho_{\text {valu }} \\
e\end{array}$ \\
\hline $\begin{array}{c}\text { Fried } \\
\text { catfish }\end{array}$ & Before & $\begin{array}{c}96,94 \\
74\end{array}$ & & - & \\
cake & After & $\begin{array}{c}98,52 \\
63\end{array}$ & 1,5789 & 3,3 & 0,0 \\
& & 63 & 45 & 01 \\
\hline
\end{tabular}

Based on table 1.4 above, it is known that the results of the test of the difference in oxygen saturation before and after treatment in third trimester pregnant women have an average before treatment of 96.9474 and an average after treatment of 98.5263 with a difference of 1.5789. The statistical results of the Wilcoxon test obtained a $\mathrm{Z}$ value of 3.345 with a significance level $\left(\rho_{\text {value }}\right)$ of 0.001 , this indicates that there is a difference in oxygen saturation before and after treatment in third trimester pregnant women.

\section{DISCUSSION}

Based on the results of research that has been carried out regarding differences in $\mathrm{Hb}$ levels in Pregnant Women Primi Gravida Trimester III before and after being given fried catfish cake, it was found that there were differences in $\mathrm{Hb}$ levels before and after treatment. This result was evidenced by the results of the $t$ statistical test where the $t_{\text {count }}$ was equal to 10.816 with a significance level of $\rho_{\text {value }}$ of 0.000 , has a significant difference because the $\rho_{\text {value }}$ is smaller than $\alpha(0.05)$. Other factors that affect hemoglobin levels include the nutritional status of the mother, if the nutritional status of the mother is lacking it will affect the hemoglobin level, and another influencing factor is the health status of the mother, the mother with anemia cases before pregnancy will affect the hemoglobin level during her pregnancy. 
According to Prasetyo (2019), pregnant women are also allowed to eat catfish because this type of fish provides many benefits for the health of themselves and the fetus in the womb. In addition to protein, the nutritional content contained in catfish starts from omega 3 fatty acids, phosphorus to vitamin B12. Regarding the large number of nutrients in catfish, it means that there are many positive benefits that pregnant women can receive when consuming it as a side dish when eating. Protein has an important role in helping the growth of the fetus and is able to maintain health during pregnancy. You need to know that inadequate protein intake can cause malnutrition.

Protein can be obtained from various types of food such as catfish. Freshwater fish have a high protein source as much as 20 percent. Catfish is not only a good source of protein, but also can be used as a complement to protein in the diet every day. Various protein content in catfish include the essential amino acids lysine, methionine and leucine. If consumed properly, the nutrients in catfish can be the best source of protein $^{8}$.

To avoid unwanted situations, nutrition during pregnancy needs to be considered. One of the foods that can prevent this risk is catfish because it contains B12. Catfish that is processed into various types will still contain B12, so it can reduce health problems during the delivery process $^{2}$.

Based on the results of research that has been carried out regarding differences in oxygen saturation in pregnant women in third trimester primi gravitas before and after being given fried catfish cake, it was found that there was a difference in oxygen saturation before and after treatment, this result was evidenced by the statistical results of the Wilcoxon test, the $\mathrm{Z}$ value was obtained at -3.345 with a significance level of value of 0.001 , Thus before and after treatment there is a significant difference because the $\rho_{\text {value }}$ is smaller than $\alpha(0.05)$.
Hemoglobin is a red blood cell pigment that carries oxygen. About 96\%$98 \%$, oxygen is able to be carried by hemoglobin. Oxygen is a substance that is needed for the continuation of physiological processes.

\section{CONCLUSION}

Brain brain fried catfish is effective in increasing hemoglobin levels and oxygen saturation in the blood in third trimester pregnant women. The strength of this research lies in the easy way of processing catfish so that it can be applied by pregnant women. The limitation of this research is that the research location is only one location. Suggestions for further researchers to continue research with samples from various ages that often occur in cases of anemia.

\begin{tabular}{lll}
\hline \multicolumn{4}{c}{ REFERENCE } \\
\hline 1. Depkes RI. 2013. Pedoman \\
penanggulangan Anemia Gizi di \\
Indonesia. Jakarta. Direktorat Bina Gizi \\
Masyarakat.
\end{tabular}

2. rasetyono, D.S. 2010. Lengkap Menu Sehat Hamil. Jogjakarta: Garailmu

3. Astawan, M. 2009. Panduan Karbohidrat Terlengkap. Jakarta: Dian Rakyat

4. West, Zita. 2010. Natural Pregnancy Panduan Lengkap Menjalani Kehamilan Secara Alamiah. Jakarta: Pustaka Bunda.

5. Direktorat Jenderal Bina Gizi Masyarakat. Buku Saku Pemantauan Status Gizi dan Indikator Kinerja Gizi Tahun 2015. Jakarta: Kementerian Kesehatan RI

6. Sugiyono. (2012). Statistika Untuk Penelitian. Bandung: ALFABETA

7. Notoatmodjo, S. (2010). Metodologi Penelitian Kesehatan. Jakarta: PT Rineka Cipta 
8. Imandira, P. A. N. 2012. Pengaruh Substitusi Tepung Daging Ikan Lele Dumbo (Clarias gariepinus) dan Tepung Ubi Jalar Kuning (Ipomoea batatas L.) terhadap Kandungan Zat Gizi dan Penerimaan Biskuit Balita Tinggi Protein dan Karoten. Artikel Penelitian. Program Studi Ilmu Gizi Fakultas Kedokteran Universitas Diponegoro: Semarang 